4

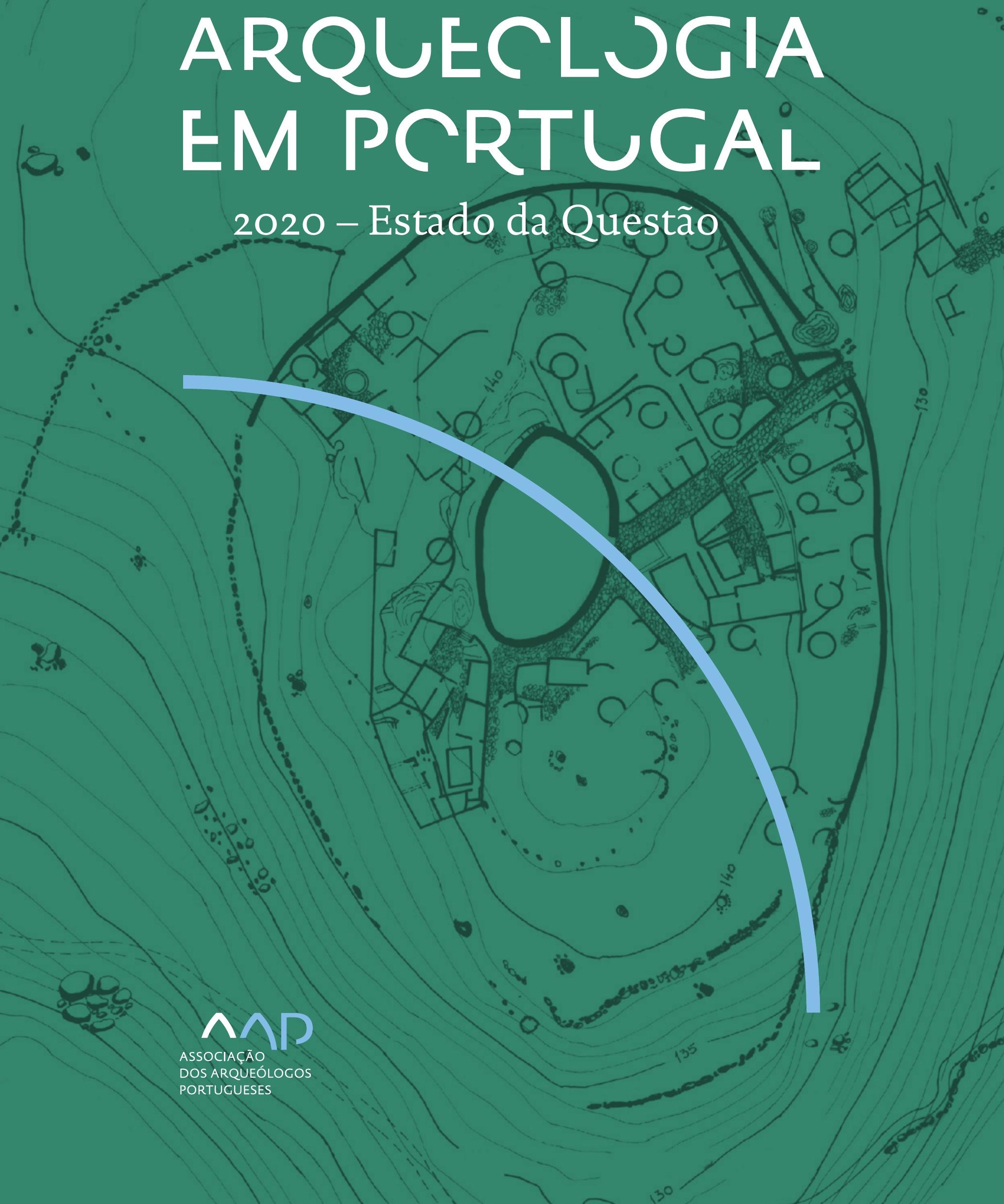


Coordenação editorial: José Morais Arnaud, César Neves e Andrea Martins Design gráfico: Flatland Design

AAP - ISBN: 978-972-9451-89-8

CITCEM - ISBN: 978-989-8970-25-1

Associação dos Arqueólogos Portugueses e CITCEM

Lisboa, 2020

O conteúdo dos artigos é da inteira responsabilidade dos autores. Sendo assim a Associação dos Arqueólogos Portugueses declina qualquer responsabilidade por eventuais equívocos ou questões de ordem ética e legal.

Desenho de capa:

Planta do castro de Monte Mozinho (Museu Municipal de Penafiel).

\section{$\hat{\wedge} \mathrm{P}$}

DOS ARQUEÓLOGOS PORTUGUESES

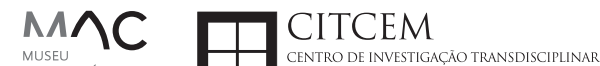
MUSEU
ARQUELLÓGICO
DO CARMO
U.PORTO

FLUP FACULDADE DE LETRAS
UNIVERSIDADE DO PORTO

Apoio

EC para a Ciência 


\section{Índice}

15 Prefácio

José Morais Arnaud

\section{Historiografia e Teoria}

17 Território, comunidade, memória e emoção: a contribuição da história da arqueologia (algumas primeiras e breves reflexões)

Ana Cristina Martins

25 Como descolonizar a arqueologia portuguesa?

Rui Gomes Coelho

41 Arqueologia e Modernidade: uma revisitação pessoal e breve de alguns aspetos da obra homónima de Julian Thomas de 2004

Vítor Oliveira Jorge

57 Dados para a História das Mulheres na Arqueologia portuguesa, dos finais do século XIX aos inícios do século XX: números, nomes e tabelas

Filipa Dimas / Mariana Diniz

73 Retractos da arqueologia portuguesa na imprensa: (in)visibilidades no feminino

Catarina Costeira / Elsa Luís

85 Arqueologia e Arqueólogos no Norte de Portugal Jacinta Bugalhão

101 Vieira Guimarães (1864-1939) e a arqueologia em Tomar: uma abordagem sobre o território e as gentes

João Amendoeira Peixoto / Ana Cristina Martins

115 Os memoráveis? A arqueologia algarvia na imprensa nacional e regional na presente centúria (2001-2019): características, visões do(s) passado(s) e a arqueologia

enquanto marca

Frederico Agosto / João Silva

129 A Evolução da Arqueologia Urbana e a Valorização Patrimonial no Barlavento Algarvio: Os casos de Portimão e Silves

Artur Mateus / Diogo Varandas / Rafael Boavida

\section{Gestão, Valorização e Salvaguarda do Património}

145 O Caderno Reivindicativo e as condições de trabalho em Arqueologia Miguel Rocha / Liliana Matias Carvalho / Regis Barbosa / Mauro Correia / Sara Simões / Jacinta Bugalhão / Sara Brito / Liliana Veríssimo Carvalho / Richard Peace / Pedro Peça / Cézer Santos

155 Os Estudos de Impacte Patrimonial como elemento para uma estratégia sustentável de minimização de impactes no âmbito de reconversões agrícolas Tiago do Pereiro

165 Salvaguarda de Património arqueológico em operações florestais: gestão e sensibilização Filipa Bragança / Gertrudes Zambujo / Sandra Lourenço / Belém Paiva / Carlos Banha / Frederico Tatá Regala / Helena Moura / Jacinta Bugalhão / João Marques / José Correia / Pedro Faria / Samuel Melro

179 Os valores do Património: uma investigação sobre os Sítios Pré-históricos de Arte Rupestre do Vale do Rio Côa e de Siega Verde José Paulo Francisco 
189 Conjugando recursos arqueológicos e naturais para potenciar as visitas ao Geoparque Litoral de Viana do Castelo (Noroeste de Portugal)

Hugo A. Sampaio / Ana M.S. Bettencourt / Susana Marinho / Ricardo Carvalhido

203 Áreas de Potencial Arqueológico na Região do Médio Tejo: Modelo Espacial Preditivo Rita Ferreira Anastácio / Ana Filipa Martins / Luiz Oosterbeek

223 Património Arqueológico e Gestão Territorial: O contributo da Arqueologia para a revisão do PDM de Avis

Ana Cristina Ribeiro

237 A coleção arqueológica do extinto Museu Municipal do Porto - Origens, Percursos e Estudos

Sónia Couto

251 Valpaços - uma nova carta arqueológica

Pedro Pereira / Maria de Fátima Casares Machado

263 Arqueologia na Cidade de Peniche

Adriano Constantino / Luís Rendeiro

273 Arqueologia Urbana: a cidade de Lagos como caso de Estudo Cátia Neto

285 Estratégias de promoção do património cultural subaquático nos Açores. O caso da ilha do Faial

José Luís Neto / José Bettencourt / Luís Borges / Pedro Parreira

297 Carta Arqueológica da Cidade Velha: Uma primeira abordagem

Jaylson Monteiro / Nireide Tavares / Sara da Veiga / Claudino Ramos / Edson Brito /

Carlos Carvalho / Francisco Moreira / Adalberto Tavares

311 Antropologia Virtual: novas metodologias para a análise morfológica e funcional Ricardo Miguel Godinho / Célia Gonçalves

\section{Didáctica da Arqueologia}

327 Como os projetos de Arqueologia podem contribuir para uma comunidade culturalmente mais consciente Alexandra Figueiredo / Claúdio Monteiro / Adolfo Silveira / Ricardo Lopes

337 Educação Patrimonial - Um cidadão esclarecido é um cidadão ativo! Ana Paula Almeida

351 A aproximação da Arqueologia à sala de aula: um caso de estudo no $3^{\circ}$ ciclo do Ensino Básico Luís Serrão Gil

363 Arqueologia 3.o - Pensar e comunicar a Arqueologia para um futuro sustentável Mónica Rolo

377 “Conversa de Arqueólogos" - Divulgar a Arqueologia em tempos de Pandemia Diogo Teixeira Dias

389 Escola Profissional de Arqueologia: desafios e oportunidades Susana Nunes / Dulcineia Pinto / Júlia Silva / Ana Mascarenhas

399 Os Museus de Arqueologia e os Jovens: a oferta educativa para o público adolescente Beatriz Correia Barata / Leonor Medeiros

411 O museu universitário como mediador entre a ciência e a sociedade: o exemplo da secção de arqueologia no Museu de História Natural e da Ciência da Universidade do Porto (MHNC-UP)

Rita Gaspar 
421 Museu de Lanifícios: Real Fábrica de Panos. Atividades no âmbito da Arqueologia Beatriz Correia Barata / Rita Salvado

427 Arqueologia Pública e o caso da localidade da Mata (Torres Novas) Cláudia Manso / Ana Rita Ferreira / Cristiana Ferreira / Vanessa Cardoso Antunes

431 Do sítio arqueológico ao museu: um percurso (também) didático Lídia Fernandes

447 Estão todos convidados para a Festa! E para dançar também... O projecto do Serviço Educativo do Museu Arqueológico do Carmo na $5^{\underline{a}}$ Edição da Festa da Arqueologia Rita Pires dos Santos

459 O “Clã de Carenque”, um projeto didático de arqueologia Eduardo Gonzalez Rocha

469 Mediação cultural: peixe que puxa carroça nas Ruínas Romanas de Troia Inês Vaz Pinto / Ana Patrícia Magalhães / Patrícia Brum / Filipa Santos

481 Didática Arqueológica, experiências do Projeto Mértola Vila Museu Maria de Fátima Palma / Clara Rodrigues / Susana Gómez / Lígia Rafael

\section{Arte Rupestre}

497 Os inventários de arte rupestre em Portugal Mila Simões de Abreu

513 O projeto FIRST-ART - conservação, documentação e gestão das primeiras manifestações de arte rupestre no Sudoeste da Península Ibérica: as grutas do Escoural e Maltravieso Sara Garcês / Hipólito Collado / José Julio García Arranz / Luiz Oosterbeek / António Carlos Silva / Pierluigi Rosina / Hugo Gomes / Anabela Borralheiro Pereira / George Nash / Esmeralda Gomes / Nelson Almeida / Carlos Carpetudo

523 Trabalhos de documentação de arte paleolítica realizados no âmbito do projeto PalæoCôa André Tomás Santos / António Fernando Barbosa / Luís Luís / Marcelo Silvestre / Thierry Aubry

537 Imagens fantasmagóricas, silhuetas elusivas: as figuras humanas na arte do Paleolítico Superior da região do Côa Mário Reis

$55^{1}$ Os motivos zoomórficos representados nas placas de tear de Vila Nova de São Pedro (Azambuja, Portugal) Andrea Martins / César Neves / José M. Arnaud / Mariana Diniz

571 Arte Rupestre do Monte de Góios (Lanhelas, Caminha). Síntese dos resultados dos trabalhos efectuados em 2007-2009 Mário Varela Gomes

599 Gravuras rupestres de barquiformes no Monte de S. Romão, Guimarães, Noroeste de Portugal Daniela Cardoso

613 Círculos segmentados gravados na Bacia do Rio Lima (Noroeste de Portugal): contributos para o seu estudo Diogo Marinho / Ana M.S. Bettencourt / Hugo Aluai Sampaio

631 Equídeos gravados no curso inferior do Rio Mouro, Monção (NW Portugal). Análise preliminar Coutinho, L.M. / Bettencourt, A.M.S / Sampaio, Hugo A.S

645 Paletas na Arte Rupestre do Noroeste de Portugal. Inventário preliminar Bruna Sousa Afonso / Ana M. S. Bettencourt / Hugo A. Sampaio 


\section{Pré-História}

661 O projeto Miño/Minho: balanço de quatro anos de trabalhos arqueológicos Sérgio Monteiro-Rodrigues / João Pedro Cunha-Ribeiro / Eduardo Méndez-Quintas / Carlos Ferreira / Pedro Xavier / José Meireles / Alberto Gomes / Manuel Santonja / Alfredo Pérez-González

677 A ocupação paleolítica da margem esquerda do Baixo Minho: a indústria lítica do sítio de Pedreiras 2 (Monção, Portugal) e a sua integração no contexto regional Carlos Ferreira / João Pedro Cunha-Ribeiro / Sérgio Monteiro-Rodrigues / Eduardo Méndez-Quintas / Pedro Xavier / José Meireles / Alberto Gomes / Manuel Santonja / Alfredo Pérez-González

693 O sítio acheulense do Plistocénico médio da Gruta da Aroeira Joan Daura / Montserrat Sanz / Filipa Rodrigues / Pedro Souto / João Zilhão

703 As sociedades neandertais no Barlavento algarvio: modelos preditivos com recurso aos SIG

Daniela Maio

715 A utilização de quartzo durante o Paleolítico Superior no território dos vales dos rios Vouga e Côa

Cristina Gameiro / Thierry Aubry / Bárbara Costa / Sérgio Gomes / Luís Luís / Carmen Manzano / André Tomás Santos

733 Uma perspetiva diacrónica da ocupação do concheiro do Cabeço da Amoreira (Muge, Portugal) a partir da tecnologia lítica Joana Belmiro / João Cascalheira / Célia Gonçalves

745 Novos dados sobre a Pré-história Antiga no concelho de Palmela. A intervenção arqueológica no sítio do Poceirão I

Michelle Teixeira Santos

757 Problemas em torno de Datas Absolutas Pré-Históricas no Norte do Alentejo Jorge de Oliveira

771 Povoamento pré-histórico nas áreas montanhosas do NO de Portugal: o Abrigo 1 de Vale de Cerdeira Pedro Xavier / José Meireles / Carlos Alves

783 Apreciação do povoamento do Neolítico Inicial na Baixa Bacia do Douro. A Lavra I (Serra da Aboboreira) como caso de estudo Maria de Jesus Sanches

797 O Processo de Neolitização na Plataforma do Mondego: os dados do Sector C do Outeiro dos Castelos de Beijós (Carregal do Sal)

João Carlos de Senna-Martinez / José Manuel Quintã Ventura / Andreia Carvalho / Cíntia Maurício

823 Novos trabalhos na Lapa da Bugalheira (Almonda, Torres Novas) Filipa Rodrigues / Pedro Souto / Artur Ferreira / Alexandre Varanda / Luís Gomes / Helena Gomes / João Zilhão

837 A pedra polida e afeiçoada do sítio do Neolítico médio da Moita do Ourives (Benavente, Portugal)

César Neves

857 Casal do Outeiro (Encarnação, Mafra): novos contributos para o conhecimento do povoamento do Neolítico final na Península de Lisboa.

Cátia Delicado / Carlos Maneira e Costa / Marta Miranda / Ana Catarina Sousa

873 Stresse infantil, morbilidade e mortalidade no sítio arqueológico do Neolítico Final/ Calcolítico ( $4^{\circ}$ e $3^{\circ}$ milénio a.C.) do Monte do Carrascal 2 (Ferreira do Alentejo, Beja) Liliana Matias de Carvalho / Sofia N. Wasterlain 
885 Come together: O Conjunto Megalítico das Motas (Monção, Viana do Castelo) e as expressões Campaniformes do Alto Minho Ana Catarina Basílio / Rui Ramos

899 Trabalhos arqueológicos no sítio Calcolítico da Pedreira do Poio Carla Magalhães / João Muralha / Mário Reis / António Batarda Fernandes

913 O sítio arqueológico de Castanheiro do Vento. Da arquitectura do sítio à arquitectura de um território João Muralha Cardoso

925 Estudo zooarqueológico das faunas do Calcolítico final de Vila Nova de São Pedro (Azambuja, Portugal): Campanhas de 2017 e 2018 Cleia Detry / Ana Catarina Francisco / Mariana Diniz / Andrea Martins / César Neves / José Morais Arnaud

943 As faunas depositadas no Museu Arqueológico do Carmo provenientes de Vila Nova de São Pedro (Azambuja): as campanhas de 1937 a 1967 Ana Catarina Francisco / Cleia Detry / César Neves / Andrea Martins / Mariana Diniz / José Morais Arnaud

959 Análise funcional de material lítico em sílex do castro de Vila Nova de S. Pedro (Azambuja, Portugal): uma primeira abordagem Rafael Lima

971 O recinto da Folha do Ouro 1 (Serpa) no contexto dos recintos de fossos calcolíticos alentejanos

António Carlos Valera / Tiago do Pereiro / Pedro Valério / António M. Monge Soares

\section{Proto-História}

987 Produção de sal marinho na Idade do Bronze do noroeste Português. Alguns dados para uma reflexão

Ana M. S. Bettencourt / Sara Luz / Nuno Oliveira / Pedro P. Simões / Maria Isabel C. Alves / Emílio Abad-Vidal

1001 A estátua-menir do Pedrão ou de São Bartolomeu do Mar (Esposende, noroeste de Portugal) no contexto arqueológico da fachada costeira de entre os rios Neiva e Cávado Ana M. S. Bettencourt / Manuel Santos-Estévez / Pedro Pimenta Simões / Luís Gonçalves

1015 O Castro do Muro (Vandoma/Baltar, Paredes) - notas para uma biografia de ocupação da Idade do Bronze à Idade Média

Maria Antónia D. Silva / Ana M. S. Bettencourt / António Manuel S. P. Silva / Natália Félix

1031 Do Bronze Final à Idade Média - continuidades e hiatos na ocupação de Povoados em Oliveira de Azeméis João Tiago Tavares / Adriaan de Man

1041 As faunas do final da Idade do Bronze no Sul de Portugal: leituras desde o Outeiro do Circo (Beja)

Nelson J. Almeida / Íris Dias / Cleia Detry / Eduardo Porfírio / Miguel Serra

1055 A Espada do Monte das Oliveiras (Serpa) - uma arma do Bronze Pleno do Sudoeste Rui M. G. Monge Soares / Pedro Valério / Mariana Nabais / António M. Monge Soares

1065 São Julião da Branca (Albergaria-a-Velha) - Investigação e valorização de um povoado do Bronze Final

António Manuel S. P. Silva / Paulo A. P. Lemos / Sara Almeida e Silva / Edite Martins de Sá

1083 Do castro de S. João ao Mosteiro de Santa Clara: notícia de uma intervenção arqueológica, em Vila do Conde Rui Pinheiro 
1095 O castro de Ovil (Espinho), um quarto de século de investigação - resultados e questões em aberto

Jorge Fernando Salvador / António Manuel S. P. Silva

1111 O Castro de Salreu (Estarreja), um povoado proto-histórico no litoral do Entre Douro e Vouga

Sara Almeida e Silva / António Manuel S. P. Silva / Paulo A. P. Lemos / Edite Martins de Sá

1127 Castro de Nossa Senhora das Necessidades (Sernancelhe): uma primeira análise artefactual Telma Susana O. Ribeiro

${ }_{1141}$ A cividade de Bagunte. O estado atual da investigação Pedro Brochado de Almeida

1153 Zoomorfos na cerâmica da Idade do Ferro no NW Peninsular: inventário, cronologias e significado Nuno Oliveira / Cristina Seoane

1163 Vasos gregos em Portugal: diferentes maneiras de contar a história do intercâmbio cultural na Idade do Ferro

Daniela Ferreira

1175 Os exotica da necrópole da Idade do Ferro do Olival do Senhor dos Mártires (Alcácer do Sal) no seu contexto regional

Francisco B. Gomes

\section{Antiguidade Clássica e Tardia}

1191 O uso de madeira como combustível no sítio da Quinta de Crestelos (Baixo Sabor): da Idade do Ferro à Romanização Filipe Vaz / João Tereso / Sérgio Simões Pereira / José Sastre / Javier Larrazabal Galarza / Susana Cosme / José António Pereira / Israel Espi

1207 Cultivos de Época Romana no Baixo Sabor: continuidade em tempos de mudança? João Pedro Tereso / Sérgio Simões Pereira / Filipe Santos / Luís Seabra / Filipe Vaz

1221 A casa romana na Hispânia: aplicação dos modelos itálicos nas províncias ibéricas Fernanda Magalhães / Diego Machado / Manuela Martins

1235 As pinturas murais romanas da Rua General Sousa Machado, n. ${ }^{5}$ 1, Chaves José Carvalho

1243 Trás do Castelo (Vale de Mir, Pegarinhos, Alijó) - Uma exploração agrícola romana do Douro

Tony Silvino / Pedro Pereira

1255 A sequência de ocupação no quadrante sudeste de Bracara Augusta: as transformações de uma unidade doméstica Lara Fernandes / Manuela Martins

1263 Os Mosaicos com decoração geométrica e geométrico-vegetalista dos sítios arqueológicos da área do Conuentus Bracaraugustanus. Novas abordagens quanto à conservação, restauro, decoração e datação Maria de Fátima Abraços / Licínia Wrench

1277 “Casa Romana” do Castro de São Domingos (Cristelos, Lousada): Escavação, Estudo e Musealização Paulo André de P. Lemos

1291 A arqueobotânica no Castro de Guifões (Matosinhos, Noroeste de Portugal): O primeiro estudo carpológico

Luís Seabra / Andreia Arezes / Catarina Magalhães / José Varela / João Pedro Tereso 
1305 Um Horreum Augustano na Foz do Douro (Monte do Castelo de Gaia, Vila Nova de Gaia) Rui Ramos

1311 Ponderais romanos na Lusitânia: padrões, formas, materiais e contextos de utilização Diego Barrios Rodríguez

1323 Um almofariz centro-itálico na foz do Mondego

Marco Penajoia

1335 Estruturas romanas de Carnide - Lisboa Luísa Batalha / Mário Monteiro / Guilherme Cardoso

1347 O contexto funerário do sector da "necrópole NO" da Rua das Portas de S. Antão (Lisboa): o espaço, os artefactos, os indivíduos e a sua interconectividade na interpretação do passado Sílvia Loja, José Carlos Quaresma, Nelson Cabaço, Marina Lourenço, Sílvia Casimiro, Rodrigo Banha da Silva, Francisca Alves-Cardoso

${ }_{1361}$ Povoamento em época Romana na Amadora - resultados de um projeto pluridisciplinar Gisela Encarnação / Vanessa Dias

1371 A Arquitectura Residencial em Mirobriga (Santiago do Cacém): contributo a partir de um estudo de caso Filipe Sousa / Catarina Felício

${ }_{1385}$ O fim do ciclo. Saneamento e gestão de resíduos nos edifícios termais de Mirobriga (Santiago do Cacém)

Catarina Felício / Filipe Sousa

1399 Balsa, Topografia e Urbanismo de uma Cidade Portuária Vítor Silva Dias / João Pedro Bernardes / Celso Candeias / Cristina Tété Garcia

1413 No Largo das Mouras Velhas em Faro (2017): novas evidências da necrópole norte de Ossonoba e da sua ocupação medieval Ricardo Costeira da Silva / Paulo Botelho / Fernando Santos / Liliana Nunes

1429 Instrumentos de pesca recuperados numa fábrica de salga em Ossonoba (Faro) Inês Rasteiro / Ricardo Costeira da Silva / Paulo Botelho

1439 A Necrópole Romana do Eirô, Duas Igrejas (Penafiel): intervenção arqueológica de 2016 Laura Sousa / Teresa Soeiro

1457 Ritual, descarte ou afetividade? A presença de Canis lupus familiaris na Necrópole Noroeste de Olisipo (Lisboa)

Beatriz Calapez Santos / Sofia Simões Pereira / Rodrigo Banha da Silva / Sílvia Casimiro / Cleia Detry / Francisca Alves Cardoso

1467 Dinâmicas económicas em Bracara na Antiguidade Tardia Diego Machado / Manuela Martins / Fernanda Magalhães / Natália Botica

1479 Cerâmicas e Vidros da Antiguidade Tardia do Edifício sob a Igreja do Bom Jesus (Vila Nova de Gaia) Joaquim Filipe Ramos

1493 Novos contributos para a topografia histórica de Mértola no período romano e na Antiguidade Tardia Virgílio Lopes

\section{8. Época Medieval}

1511 Cerâmicas islâmicas no Garb setentrional "português": algumas evidências e incógnitas Constança dos Santos / Helena Catarino / Susana Gómez / Maria José Gonçalves / Isabel Inácio / Gonçalo Lopes / Jacinta Bugalhão / Sandra Cavaco / Jaquelina Covaneiro / Isabel Cristina Fernandes / Ana Sofia Gomes 
1525 Contributo para o conhecimento da cosmética islâmica, em Silves, durante a Idade Média Rosa Varela Gomes

1537 Yábura e o seu território - uma análise histórico-arqueológica de Évora entre os séculos VIII-XII José Rui Santos

1547 A encosta sul do Castelo de Palmela - resultados preliminares da escavação arqueológica Luís Filipe Pereira / Michelle Teixeira Santos

1559 A igreja de São Lourenço (Mouraria, Lisboa): um conjunto de silos e de cerâmica medieval islâmica

Andreia Filipa Moreira Rodrigues

1571 O registo material de movimentações populacionais no Médio Tejo, durante os séculos XII-XIII. Dois casos de "sunken featured buildings", nos concelhos de Cartaxo e Torres Novas Marco Liberato / Helena Santos / Nuno Santos

1585 O nordeste transmontano nos alvores da Idade média. Notas para reflexão Ana Maria da Costa Oliveira

1601 Sepulturas escavadas na rocha do Norte de Portugal e do Vale do Douro: primeiros resultados do Projecto SER-NPVD

Mário Jorge Barroca / César Guedes / Andreia Arezes / Ana Maria Oliveira

1619 "Portucalem Castrum Novum" entre o Mediterrâneo e o Atlântico: o estudo dos materiais cerâmicos alto-medievais do arqueossítio da rua de D. Hugo, nํ. 5 (Porto) João Luís Veloso

1627 A Alta Idade Média na fronteira de Lafões: notas preliminares sobre a Arqueologia no Concelho de Vouzela

Manuel Luís Real / Catarina Tente

1641 Um conjunto cerâmico medieval fora de portas: um breve testemunho aveirense Susana Temudo

${ }_{1651}$ Os Lóios do Porto: uma perspetiva integrada no panorama funerário da Baixa Idade Média à Época Moderna em meios urbanos em Portugal

Ana Lema Seabra

1659 O Caminho Português Interior de Santiago como eixo viário na Idade Média Pedro Azevedo

1665 Morfologia Urbana: Um exercício em torno do Castelo de Ourém André Donas-Botto / Jaqueline Pereira

1677 Intervenção arqueológica na Rua Marquês de Pombal/Largo do Espírito Santo (Bucelas, Loures)

Florbela Estêvão / Nathalie Antunes-Ferreira / Dário Ramos Neves / Inês Lisboa

1691 O Cemitério Medieval do Poço do Borratém e a espacialidade funerária na cidade de Lisboa Inês Belém / Vanessa Filipe / Vasco Noronha Vieira / Sónia Ferro / Rodrigo Banha da Silva

1705 Um Espaço Funerário Conventual do séc. XV em Lisboa: o caso do Convento de São Domingos da Cidade Sérgio Pedroso / Sílvia Casimiro / Rodrigo Banha da Silva / Francisca Alves Cardoso

\section{9. Época Moderna e Contemporânea}

1721 Arqueologia Moderna em Portugal: algumas reflexões críticas em torno da quantificação de conjuntos cerâmicos e suas inferências históricas e antropológicas Rodrigo Banha da Silva / André Bargão / Sara da Cruz Ferreira

1733 Faianças de dois contextos entre os finais do século XVI e XVIII do Palácio dos Condes de Penafiel, Lisboa

Martim Lopes / Tomás Mesquita 
1747 Um perfil de consumo do século XVIII na foz do Tejo: O caso do Mercado da Ribeira, Lisboa Sara da Cruz Ferreira / Rodrigo Banha da Silva / André Bargão

1761 Os Cachimbos dos Séculos XVII e XVIII do Palácio Mesquitela e Convento dos Inglesinhos (Lisboa)

Inês Simão / Marina Pinto / João Pimenta / Sara da Cruz Ferreira / André Bargão / Rodrigo Banha da Silva

1775 "Tomar os fumos da erua que chamão em Portugal erua sancta». Estudo de Cachimbos provenientes da Rua do Terreiro do Trigo, Lisboa

Miguel Martins de Sousa / José Pedro Henriques / Vanessa Galiza Filipe

1787 Cachimbos de Barro Caulínitico da Sé da Cidade Velha (República de Cabo Verde)

Rodrigo Banha da Silva / João Pimenta / Clementino Amaro

1801 Algumas considerações sobre espólio não cerâmico recuperado no Largo de Jesus (Lisboa) Carlos Boavida

1815 Adereços de vidro, dos séculos XVI-XVIII, procedentes do antigo Convento de Santana de Lisboa (anéis, braceletes e contas)

Joana Gonçalves / Rosa Varela Gomes / Mário Varela Gomes

1837 Da ostentação, luxo e poder à simplicidade do uso quotidiano: arqueologia e simbologia de joias e adornos da Idade Moderna Portuguesa Jéssica Iglésias

1849 Os amuletos em Portugal - dos objetos às superstições: o coral vermelho Alexandra Vieira

1865 Cerâmicas de Vila Franca de Xira nos séculos XV e XVI Eva Pires

1879 «Não passa por teu o que me pertence». Marcas de individualização associadas a faianças do Convento de Nossa Senhora de Aracoeli, Alcácer do Sal Catarina Parreira / Íris Fragoso / Miguel Martins de Sousa

1891 Cerâmica de Leiria: alguns focos de produção

Jaqueline Pereira / André Donas-Botto

1901 Os Fornos na Rua da Biquinha, em Óbidos Hugo Silva / Filipe Oliveira

1909 A casa de Pêro Fernandes, contador dos contos de D. Manuel I: o sítio arqueológico da Silha do Alferes, Seixal (século XVI) Mariana Nunes Ferreira

1921 O Alto da Vigia (Sintra) e a vigilância e defesa da costa Alexandre Gonçalves / Sandra Santos

1937 O contexto da torre sineira da Igreja de Santa Maria de Loures Paulo Calaveira / Martim Lopes

1949 A Necrópole do Hospital Militar do Castelo de São Jorge e as práticas funerárias na Lisboa de Época Moderna Susana Henriques / Liliana Matias de Carvalho / Ana Amarante / Sofia N. Wasterlain

1963 SAND - Sarilhos Grandes Entre dois Mundos: o adro da Igreja e a Paleobiologia dos ossos humanos recuperados

Paula Alves Pereira / Roger Lee Jesus / Bruno M. Magalhães

1975 Expansão urbana da vila de Cascais no século XVII e XVIII: a intervenção arqueológica na Rua da Vitória no 15 a 17

Tiago Pereira / Vanessa Filipe

1987 Novos dados para o conhecimento do Urbanismo de Faro em época Moderna Ana Rosa 
1995 Um exemplo de Arqueologia Urbana em Alcoutim: o Antigo Edifício dos CTT Marco Fernandes / Marta Dias / Alexandra Gradim / Virgílio Lopes / Susana Gómez Martínez

2007 Palácio dos Ferrazes (Rua das Flores/Rua da Vitória, Porto): a cocheira de Domingos Oliveira Maia

Francisco Raimundo

2021 As muitas vidas de um edifício urbano: História, Arqueologia e Antropologia no antigo Recreatório Paroquial de Penafiel Helena Bernardo / Jorge Sampaio / Marta Borges

2035 O convento de Nossa Senhora da Esperança de Ponta Delgada: o contributo da arqueologia para o conhecimento de um monumento identitário João Gonçalves Araújo / N’Zinga Oliveira

2047 Arqueologia na ilha do Corvo... em busca da capela de Nossa Senhora do Rosário Tânia Manuel Casimiro / José Luís Neto / Luís Borges / Pedro Parreira

2059 Perdidos à vista da Costa. Trabalhos arqueológicos subaquáticos na Barra do Tejo Jorge Freire / José Bettencourt / Augusto Salgado

2071 Arqueologia marítima em Cabo Verde: enquadramento e primeiros resultados do projecto CONCHA

José Bettencourt / Adilson Dias / Carlos Lima / Christelle Chouzenoux / Cristóvão Fonseca / Dúnia Pereira / Gonçalo Lopes / Inês Coelho / Jaylson Monteiro / José Lima / Maria Eugénia Alves / Patrícia Carvalho / Tiago Silva

2085 Trabalhos arqueológicos na Cidade Velha (Ribeira Grande de Santiago, Cabo Verde): reflexões sobre um projecto de investigação e divulgação patrimonial André Teixeira / Jaylson Monteiro / Mariana Mateus / Nireide Tavares / Cristovão Fonseca / Gonçalo C. Lopes / Joana Bento Torres / Dúnia Pereira / André Bargão / Aurélie Mayer / Bruno Zélie / Carlos Lima / Christelle Chouzenoux / Inês Henriques / Inês Pinto Coelho / José Lima / Patrícia Carvalho / Tiago Silva

2103 A antiga fortificação de Quelba / Khor Kalba (E.A.U.). Resultados de quatro campanhas de escavações, problemáticas e perspectivas futuras Rui Carita / Rosa Varela Gomes / Mário Varela Gomes / Kamyar Kamyad

2123 Colónias para homens novos: arqueologia da colonização agrária fascista no noroeste ibérico Xurxo Ayán Vila / José Mạ . Señorán Martín 


\title{
ESTRUTURAS ROMANAS DE CARNIDE - LISBOA
}

\author{
Luísa Batalha ${ }^{1}$, Mário Monteiro² ${ }^{2}$ Guilherme Cardoso ${ }^{3}$
}

\begin{abstract}
RESUMO
Os trabalhos arqueológicos realizados no Palácio Sant'Anna, Carnide (Lisboa) revelaram a presença romana através de restos de um piso em opus signinum, possivelmente de um tanque e um poço escavado no geológico, com boca circular de alvenaria seca, colmatado com terra, pedras e materiais daquele período. Entre os materiais de época romana recolhidos, destacam-se: fragmentos de recipientes de terra sigillata, ânforas Lusitanas e Béticas, cerâmica comum, assim como um dormente de mó em arenito, elementos que apontam para uma ocupação do sítio entre os séculos I-III d.C.

Palavras-chave: Carnide, Período Romano, Poço, Cerâmica Romana.
\end{abstract}

\begin{abstract}
The archeological excavations carried out at Sant'Anna Palace, Carnide (Lisbon) revealed Roman occupation documented by the remains of an opus signinum coated pavement. Possibly a tank or a well dug in bed rock, circle shaped built with dry stone masonry. It was deactivated and filled with dirt, stones and other archeological materials. Standing out among the collected Roman materials we can find: terra sigillata ceramic fragments, Lusitana and Bética type amphoras, common ceramic, as well as static part of a sandstone millstone, which lead us to the conclusion that this place was occupied between the $1^{\text {st }}$ and $3^{\text {rd }}$ centuries A. C.
\end{abstract}

Keywords: Carnide, Roman Period, Well, Roman Pottery.

\section{ENQUADRAMENTO GEOGRÁFICO E GEOLÓGICO}

A intervenção arqueológica foi realizada na Rua da Fonte, n. ${ }^{\circ}$ 41-51, em Carnide, concelho de Lisboa, à cota dos 104/105 metros.

Esta área da cidade de Lisboa encontra-se sobre unidades geológicas do Complexo Miocénico do Burdigaliano, (Pais et al., 2006). Localiza-se sobre uma unidade dos "Calcários de Entre Campos" também designados por "Banco Real”, que são atribuídos à sequência deposicional Bı (Pais et al., 2006).

Constituída por biocalcalcarenitos, com componente detrítica e por acumulação de conchas e moldes, ligados por cimento carbonatado, incluem ainda calcarenitos finos, margosos e arenitos micáceos pouco carbonatados. No topo, evolui para areias muito finas e siltitos argilosos de cor acinzenta. Passando progressivamente á formação superior, observam-se as "Argilas do Forno do Tijolo", atingindo espessuras da ordem dos 12 a 17m (Cotter, 1956).

\section{RESUMO HISTÓRICO}

A zona de Carnide, Lisboa, é um local onde uma longa diacronia temporal se encontra preservada no subsolo, bem como no património construído, presente na sua zona histórica. Ainda que dos vestígios pré-históricos e romanos apenas existam vagas notícias e alguns achados, a ocupação do período Medieval Islâmico carece de elementos significativos, indicadores das vivências desta época, como consequência de neste local ter funcionado um espaço de enterramento, cujas características de inumação o identificaram e dataram de época islâmica. Entre as referências da existência de quintas senhoriais des-

\footnotetext{
1. Associação Cultural de Cascais

2. EMERITA, Lda.

3. CAL, (Centro de Arqueologia de Lisboa) e Associação Cultural de Cascais
} 
de meados do século XIV, encontra-se o paço real de Carnide (em 1313, era Carnide uma aldeia com seu rocio). Após o terramoto de 1755, que muito terá afetado a zona, dá-se um incremento construtivo, tendo o mesmo, em grande parte, permanecido conservado até à atualidade.

Os trabalhos arqueológicos realizados pela EMERITA no Palácio Sant'Anna - também designado por Palácio da Praça ou Quinta da Praça - revelaram, que a última ocupação do palácio ocorreu já nos finais do século $\mathrm{XX}$, mais propriamente entre as décadas de 70-80, data em que, por motivo de um incêndio, se verificou em definitivo o seu abandono. No solo, um considerável espólio arqueológico atestou a ocupação do espaço desde a Pré-História recente, mas, também as construções de outras eras ficaram ocultadas e preservadas, pelas que se lhe foram sobrepondo, e, consequentemente, alteando a cota do palácio.

\section{OS VESTÍGIOS ROMANOS}

Não era de todo desconhecida a presença romana em Carnide, sendo esta apoiada através de alguns vestígios, tais como as duas tampas cupiformes que surgiram há alguns anos, uma na esquina da Travessa do Pregoeiro com a Rua Neves Costa e outra oriunda do Largo da Praça, n⿳⺈ 7, com a Travessa do Pregoeiro (Cardoso \& Gonzalez, 2008, p. 6).

Durante uma escavação realizada no edifício entre o Largo da Praça, n.. 7 e a Travessa do Pregoeiro, n.. 2, foi recolhido no interior de uma bolsa, um pequeno fragmento de opus signinum, junto a materiais pré-históricos e contemporâneos (Monteiro \& Cardoso, 2016, p. 48, 62).

No edifício nº 84/86 da Rua Neves Costa, durante o acompanhamento de reabilitação, foi recolhido um fragmento de uma ara votiva, reaproveitada no aparelho construtivo das paredes do século XIX, bem como fragmentos de um possível friso romano, encontrando-se estes reutilizados ornamentalmente, no pátio interior do no 82 da mesma rua (Cuesta-Gómez \& Prata, 2017, 601).

Localiza-se Carnide entre as quatro e as cinco milhas romanas de Olisipo, junto a uma das antigas vias que ligava a zona Oeste do ager olisiponesis. Partia do Rossio através da Rua das Portas de Santo Antão, ligando a Carnide e dali seguia para a villa romana da Bolacha, Amadora, de onde bifurcava para Oeste, através do território dos actuais concelhos de Oeiras e Cascais até ao Guincho, enquanto um segundo ramal seguia para o concelho de Sintra até São João das Lampas, passando nas cercanias de Faião e Odrinhas.

\subsection{As Estruturas Romanas}

Durante as escavações arqueológicas efetuadas no interior do antigo palácio de Sant'Anna, para além de materiais romanos recolhidos em unidades estratigráficas sob os pisos de época Contemporânea, identificou-se no canto Sudeste, junto à fachada do edifício que dá para a rua da Fonte, a cerca de $20 \mathrm{~cm}$ de profundidade, o que restava de um pedaço de piso de opus signinum. Devido ao seu tamanho, encontrando-se muito danificado e não apresentando qualquer limite lateral da superfície a que pertencia, tornou-se impossível relacioná-lo com algum tipo de estrutura, desconhecendo-se se fazia parte de um tanque ou de um piso de uma habitação. No entanto, somos tentados a pensar que seria efectivamente um tanque, implantado junto à antiga via, que certamente por ali passaria, e que hoje é a rua da Fonte. Sob o arco Sul da cozinha de época Contemporânea, a sete metros de distância para Noroeste do referido piso de opus signinum, identificou-se uma estrutura negativa, correspondendo a um poço circular, aberto no subsolo dos "calcários de Entrecampos", com 1,5 m de diâmetro ao nível da boca e 1,2 m de diâmetro no seu interior, tendo sido colmatado em época romana.

A escavação atingiu a profundidade de 4,2 $\mathrm{m}$, não sendo possível dar continuidade aos trabalhos, devido ao perigo de desabamento da estrutura, bem como, ter sido ultrapassada a cota de afetação da obra. Na área da boca deste poço, ainda existiam vestígios de um muro de pedra solta de dupla fiada.

$\mathrm{Na}$ parede interna observaram-se diversos orifícios, localizados a cotas distintas e desalinhados, depreendendo-se que foram utilizados para facilitar a escalada, em caso de necessidade de limpeza.

No seu interior identificaram-se três UEs: a primeira camada correspondia à última fase de enchimento [C18a]. Continha algumas pedras provenientes do derrube da guarda do poço, nódulos de argamassa rosada, cerâmica comum e de construção; a segunda camada de enchimento [C18b], encontrava-se encostada à parede Norte do poço e incluía igualmente nódulos de argamassa rosada, e tal como na camada anterior, cerâmica comum e de construção; a terceira unidade estratigráfica [C18c,] encontrava-se entre $1,5 \mathrm{~m}$ até aos $4,2 \mathrm{~m}$ de profundidade. Nesta, no meio 
da terra do enchimento, havia uma concentração de pedras de grande dimensão, como consequência do derrube ocorrido na metade Sul da estrutura. Incluía nódulos de argamassa rosada, um dormente de mó, fragmentos de terra sigillata, ânforas, cerâmica comum e cerâmica de construção.

\subsection{Os Materiais}

Terra sigillata

No compartimento da cozinha, UE [Cog], recolheram-se três fragmentos de parede em terra sigillata itálica, correspondendo a duas peças diferentes de forma indeterminada.

$\mathrm{Na}$ UE [C18e] foi recolhido um fragmento de terra sigillata hispânica, provavelmente de Trício, do tipo Drag. 27, datável entre 40-200 d.C. (Fonseca, 2004, p. 427).

De terra sigillata sudgálica, foram exumados do interior do poço, UE [C18b], um fragmento de parede indeterminada e na UE [C18c] um fragmento de bordo de prato, de tipo igualmente indeterminado (n. ${ }^{2}$ ).

Foi também recolhido, na UE [C18c], um fragmento de bordo de taça de terra sigillata africana A, tipo Hayes 14/15 III (n.ํㅜ), datável entre os finais do séc. II a inícios do séc. III (Cardoso, 2018, p. 272) e das lamas provenientes da UE [C18], um fragmento de pé de terra sigillata africana $\mathrm{A} / \mathrm{D}$, de forma indeterminada (n. $\left.{ }^{-} 4\right)$.

\section{Ânforas}

$\mathrm{Na}$ antiga adega, localizada no canto Noroeste do edifício, a mais de vinte metros do poço, na UE [Ao4], recolheu-se um fragmento de boca de ânfora Dressel 7/11, (n. ${ }^{\circ}$ 5), apresentando cor cinzento claro amarelada (Munsell 2.5Y8/2). Um segundo fragmento do mesmo tipo (Figura 6) foi exumado na zona da cozinha UE [Co9], apresentando pasta cor bege claro (Munsell 2.5Y7/2), ambas produzidas na Bética, sendo possível data-las entre 15 a.C. e inícios do século II d.C. (Cardoso, 2018, pp. 301 e 302), utilizadas no transporte de derivados piscícolas.

Do interior do poço, UE [C18c], foram recuperados vários fragmentos de ânforas do tipo Lusitana 3 ou Almagro 51c, dos quais apresentamos dois bordos e duas asas (n.. ${ }^{\circ}$ 7-10), com lábios em fita ligeiramente curvos, apresentando uma ou duas caneluras e ressalto em barbela na ligação ao colo. As pastas são de cor vermelha (Munsell 2.5Y6/8) ou vermelho acastanhado (Munsell 2.5Y5/6), características das figlinae do Tejo/Sado. Eram ânforas que serviam fundamentalmente para o transporte de vinho. Apresentam cronologia dos inícios do século II d. C. a meados do século III d. C. (Cardoso, 2018, p. 307), com especial relevância para as que se encontram apoiadas nas cronologias de um conjunto de exemplares recolhidos em Sevilha, no Patio de Banderas e que foram datados dos finais do século II d. C. inícios do século III d. C. (Garcia Vargas, 2016, p. 411). De entre as ânforas provenientes do poço, UE [C18c], registamos mais dois fragmentos de ânforas do tipo Almagro 50, lusitana (nº 11 e 12), também elas produzidas com as características pastas avermelhadas do Tejo/Sado (Munsell 2.5Y6/8). O início da produção deste tipo de ânfora dá-se na figlina de Porto dos Cacos, em finais do século II d. C. ao primeiro terço do século III d. C., e na figlina da Quinta do Rouxinol em finais do século II, sendo ali produzida até ao primeiro quartel do século $\mathrm{V}$ (Raposo \& Almeida, 2016).

Durante a escavação de blocos delimitativos foi retirada uma asa de ânfora de forma indeterminada (n.. 13). A pasta, de cor bege (Munsell 7.5YR6/4) é característica da região da Bética.

\section{Cerâmica Comum}

Entre os materiais recuperados mais antigos, em cerâmica comum, temos um conjunto de fragmentos de cerâmica castanha e cinzenta, característica das produções regionais, indígenas, como são os casos da boca de jarro (n.. 14 ) de pasta castanha escura, fina (Munsell 5 YR4/6), bem como da asa de secção circular (n. ${ }^{17}$ ) de pasta cinzenta escura (Munsell ${ }_{5} \mathrm{YR}_{3} / 1$ ), ambas provenientes da zona da cozinha UE [Cog], semelhantes a exemplares recolhidos em Freiria, num contexto de uma antiga pedreira da Idade do Ferro, em MZ' e que foi datado entre o século III a.C. e o I a.C. (Cardoso \& Encarnação, 2013, p. 160). Uma taça de perfil completo (n. ${ }^{-}$15) de pasta cinzenta, brunida internamente (Munsell 5YR6/1), proveniente da sala 5, UE [505], e um pequeno fragmento (n.. 16 ) de pasta cinzenta, brunida internamente (Munsell 5YR6/1), proveniente da cozinha, UE [Cog], são nitidamente produções regionais, influenciadas pelo gosto romano dos finais do século II - I a.C. a finais do século I a. C. (Cardoso, 2018, p. 325 , fig. 250 e 251).

Proveniente do poço, UE [C18c] existe um bordo provável de garrafa (n.. $\left.{ }^{18}\right)$, apresentando pasta castanha avermelhada (Munsell $5 \mathrm{YR}_{5} / 6$ ), semelhante no lábio a uma garrafa de Reguengos, datável de 
meados do século II d. C. (Nolen, 1985, 50, fig. 80). Também da mesma UE foram exumados fragmentos de bilhas de boca larga, como é o caso da boca vertical, com lábio triangular (n.ำ19), pasta rosada (Munsell 5YR7/6) ou um outro, de boca ligeiramente exvasada e lábio rectangular (n.․ 20), pasta castanha (Munsell 5YR5/3) com paralelos em Freiria, datado dos séculos I d.C. ao IV d.C. (Cardoso, 2018, p. 332, fig. 256 , n. - 44 e 5). Do mesmo contexto, foi recolhido um fundo de bilha globular (n. ${ }^{-21}$ ), de pasta alaranjada (Munsell 5YR6/8), muito semelhante a um exemplar proveniente de uma das necrópoles do alto Alentejo, publicada por Jeannette Nolen, datando-o dos finais do século I d.C. a inícios do II d.C. (1985, p. 45, fig. 65).

Do interior do poço, UE [C18c], foi retirado um fragmento de asa de bilha (n.. 22), de pasta alaranjada (Munsell 5YR6/8) e na área da cozinha, UE [Cog], uma outra asa, também de bilha (n.․ 23), de pasta rosa pálido (Munsell 5 YR8/3).

Bilhas de boca larga, apresentando bojo mais ou menos periforme, temos dois exemplares. Um, recolhido no interior do poço, UE [C18c], (n.. 24), de pasta laranja (Munsell 2.5YR6/8) e outro na parte superior (n.․ 25), de pasta laranja escura (Munsell 2.5 $\mathrm{YR}_{5} / 8$ ), UE [C18b], datados dos finais do século I d.C. aos finais do século II d.C.

Ainda da parte superior do poço, UE [C18b], registou-se um grande fragmento de tigela (n.. 26), de pasta laranja (Munsell 2.5YR6/8), semelhante a um exemplar proveniente de uma necrópole do Alto Alentejo, com cronologia atribuível entre o século I d.C. e os inícios do século III (Nolen, 1985, p. 100, fig. 372).

Um fragmento de bordo de prato com inflexão interna (n.. 27 ), de pasta laranja (Munsell 2.5YR6/8), foi retirado do interior da estrutura, UE [C18c]. Trata-se de uma forma, com datação lata, da $2^{\underline{a}}$ metade do século I d.C. aos inícios do século IV d.C. (Nolen, 1985, p. 85 , fig. 258).

O interior do poço, UE [C18c], ofereceu também um pote de bojo brunido e bordo plano, exvasado (n.․ 28), de pasta castanha alaranjada (Munsell 2.5YR5/6). No mesmo estrato foi recolhido um fragmento de panela, de bordo em aba (n.․ 29), com pasta castanha alaranjada (Munsell 2.5 $\mathrm{YR}_{5} / 6$ ), encontrando-se um paralelo para este no Castelo de Alcácer do Sal, datado da segunda metade do século I d.C. aos inícios do século II d. C. (Silva et alii, 198081, p. 201, fig. 24, 303).
Da zona da cozinha, UE [Cog], foi recolhido um fragmento de boca de pote, forma em S (n.. 30 ), de pasta laranja acastanhado (Munsell ${ }_{5} \mathrm{YR}_{5} / 8$ ). Existem paralelos para este modelo em Conimbriga, datado entre o principado de Cláudio e o de Tibério (Alarcão, 1974, p. 83 e 158, n.․ 409).

Esta estrutura ofereceu ainda, na UE [C18c], um bordo de pote, em aba (n.․ 31 ), de pasta laranja escura (Munsell 2.5YR5/8), sendo que, em Conimbriga, este tipo foi recolhido em estratos que vão de $\mathrm{Au}$ gusto a Trajano (Alarcão, 1974, p. 53 e 150, n.o 81B). Da UE [C18c], são provenientes os quatro fragmentos de fundos de potes: o (n. ${ }^{\circ}$ 32) com pasta laranja (Munsell 2.5YR6/8); o (n.. 33), também de pasta laranja (Munsell 5YR6/6); o (n.․ㅜ 34), apresentando pasta cinzenta acastanhada (Munsell 1oYR5/2) e no fundo interno, vestígios de uma camada negra. Finalmente, o (n.. 35), que apresenta pasta alaranjada (Munsell 5YR6/8).

\subsection{Mó}

Durante a escavação do poço, UE [C18c], foi recolhido um dormente de mó, cónico, de arenito de grão grosso, com um diâmetro de $35,8 \mathrm{~cm}$. Encontrava-se a cerca de $2,5 \mathrm{~m}$ de profundidade, o que pressupõe, ter sido ali lançado como entulho após o seu abandono (Figura 9 e 10).

\section{A MODO DE CONCLUSÃO}

Através dos trabalhos arqueológicos efectuados no Palácio de Sant'Anna, ficou finalmente comprovada a ocupação romana em Carnide na antiguidade, entre o século I d.C. e os inícios do século III d.C. Contudo, devido aos vestígios materiais serem pouco significativos ao nível das estruturas, apresentando unicamente um poço escavado no subsolo, conjuntamente com um piso de opus signinum, num sítio que teve ocupação pelo menos dois séculos, não nos é permitido, de momento, avançar com outras considerações.

Pelo tipo de peças encontradas, mó, cerâmicas finas e cerâmica comum, podemos deduzir tratar-se da uma ocupação de um espaço rural de pequena dimensão, ainda que os moradores possuíssem algum poder económico para importarem cerâmica em terra sigillata itálica, sudgálica, hispânica e africana. Consumiam conservas de derivados piscícolas produzidos na Bética e na Lusitânia e vinho, também em ânforas lusitanas. 
A recolha de uma ara e duas cupas nas proximidades do palácio de Sant'Anna indicia a existência de uma necrópole da mesma época, colocando-se a hipótese de estarmos nas imediações de uma villa romana, da qual ainda não se encontrou o núcleo principal.

\section{BIBLIOGRAFIA}

ALARCÃO, Jorge de (1974) - Cerâmica comum local e regional de Conimbriga. Suplemento de Biblos, 8, Coimbra.

ALMEIDA, F. M. (1986) - Carta Geológica do Concelho de Lisboa, Folha 1, na Escala 1:10 ooo. Lisboa. Serviços Geológicos de Portugal.

BERKELLY-COTTER, J. C. (1956) - O Miocénico Marinho de Lisboa. Comunicações dos Serviços Geológicos de Portugal, Suplemento do Tomo XXXVI, Lisboa.

CARDOSO, Guilherme (2018) - Villa Romana de Freiria, Estudo Arqueológico. Câmara Municipal de Cascais. Cascais.

CARDOSO, Guilherme \& ENCARNAÇÃO, José d' (2013) - O povoamento pré-romano de Freiria - Cascais. Cira Arqueologia, 2, Vila Franca de Xira, pp. 133-18o.

CARDOSO, Guilherme \& GONZALEZ, António (2008) - Duas cupas romanas em Carnide (Lisboa). Al-madan, II série, n. ․ 16, Almada, p. 6.

CUESTA-GÓMEZ, J. Fabian \& PRATA, Sara (2017) - Uma ara romana recuperada em Carnide, Lisboa (Conventus Scallabitanus). Ficheiro Epigráfico, 148, ํㅜㅇㅣ.

FONSECA, Cristóvão Pimentel (2004) - Revista Portuguesa de Arqueologia, Vol. 7, ํํ⒈ Lisboa, pp. 421-449.

GARCIA VARGAS, Enrique (2016) - Ánforas vinarias de los contextos severianos del Patio de Banderas de Sevilla. In Aguilera Aragón, Isidro.; BELTRÁN LLORIS, Francisco; DUEÑAS JIMÉNEZ, María J.; LOMBA SERRANO, Concepción; PAZ PERALTA, Juan Á., eds. - De las Ánforas al Museo. Estudios dedicados a Miguel Beltrán, Zaragoza, 2015, pp. 395-412.

MONTEIRO, Mário \& CARDOSO, Guilherme (2016) Vestígios arqueológicos identificados no Largo da Praça (Carnide, Lisboa). Emerita - Estudos de Arqueologia e Património Cultural, n.. 2, Oeiras, pp. 46-62.

NOLEN, Jeannette U. S. (1985) - Cerâmica comum de necrópoles do Alto Alentejo. Fundação da Casa de Bragança, Lisboa.

NOLEN, Jeannette U. S. (1985) - A villa romana do Alto do Cidreira (Alcabideche - Cascais). Conimbriga, XXVII, Coimbra, pp. 61-140.

PAIS, J.; Moniz C.; CABRAL, J.; CARDOSO, J. L.; LEGOINHA, P.; MACHADO, S.; MORAIS, M. A.; LOURENÇO, C.; RIBEIRO, M. L.; HENRIQUES, P.; FALÉ, P. (2006) - Notícia Explicativa Folha $34-D$, da Carta Geológica de Lisboa, na Escala 1:50 ooo. Lisboa. Instituto Nacional de Engenharia, Tecnologia e Inovação, Departamento de Geologia.

RAPOSO, Jorge M. C. \& ALMEIDA, Rui R. (2016)-Almagro 50 (Western Lusitania). Amphorae ex Hispania. Landscapes of production and consumption. (http://amphorae.icac.cat/ amphora/almagro-5o-western-lusitania), 8 July, 2016.

SANTOS, Cézer R.; RAPOSO, Jorge; QUARESMA, José C. (2015) - Análise crono-estratigráfica da Olaria Romana da Quinta do Rouxinol (Corroios, Seixal). In QUARESMA, José Carlos \& MARQUES, João António, coords. - Contextos Estratigráficos na Lusitânia (do Alto Império à Antiguidade Tardia). Lisboa: Associação Arqueólogos Portugueses, pp. 117-148 (Monografias, 1 - Actas do Colóquio Contextos Estratigráficos Romanos na Lusitania: da República à Antiguidade Tardia, Lisboa, 2012).

SILVA, Carlos T. SOARES, Joaquina; BEIRÃO, Caetano M.; DIAS, Luísa F.; COELHO-SOARES, Antónia (1980-81) - Escavações arqueológicas no Castelo de Alcácer do Sal (Campanha de 1979). Setúbal Arqueológica, VI-VII, Setúbal, pp. 149-218. 


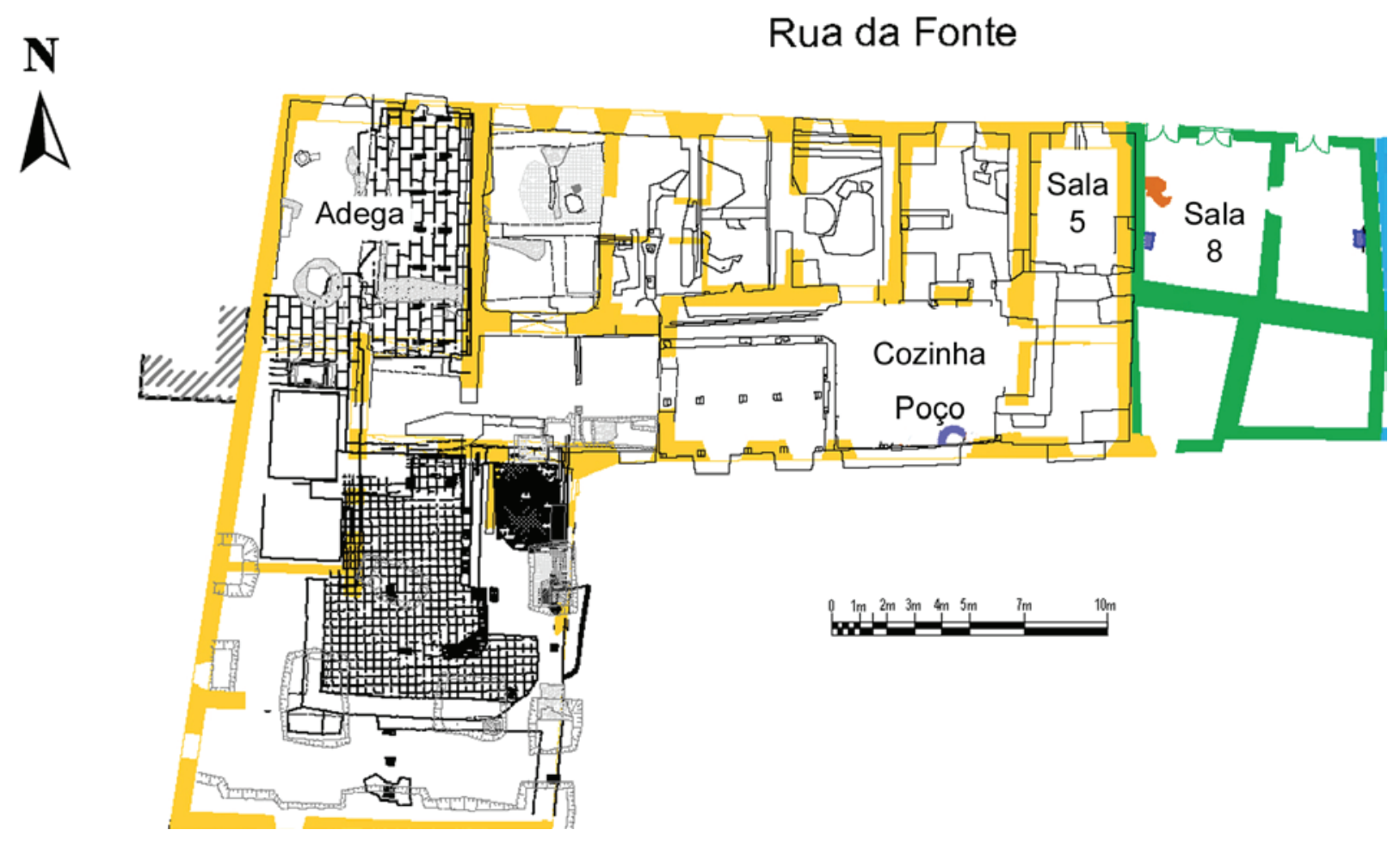

Figura 1 - Planta da área do Palácio.
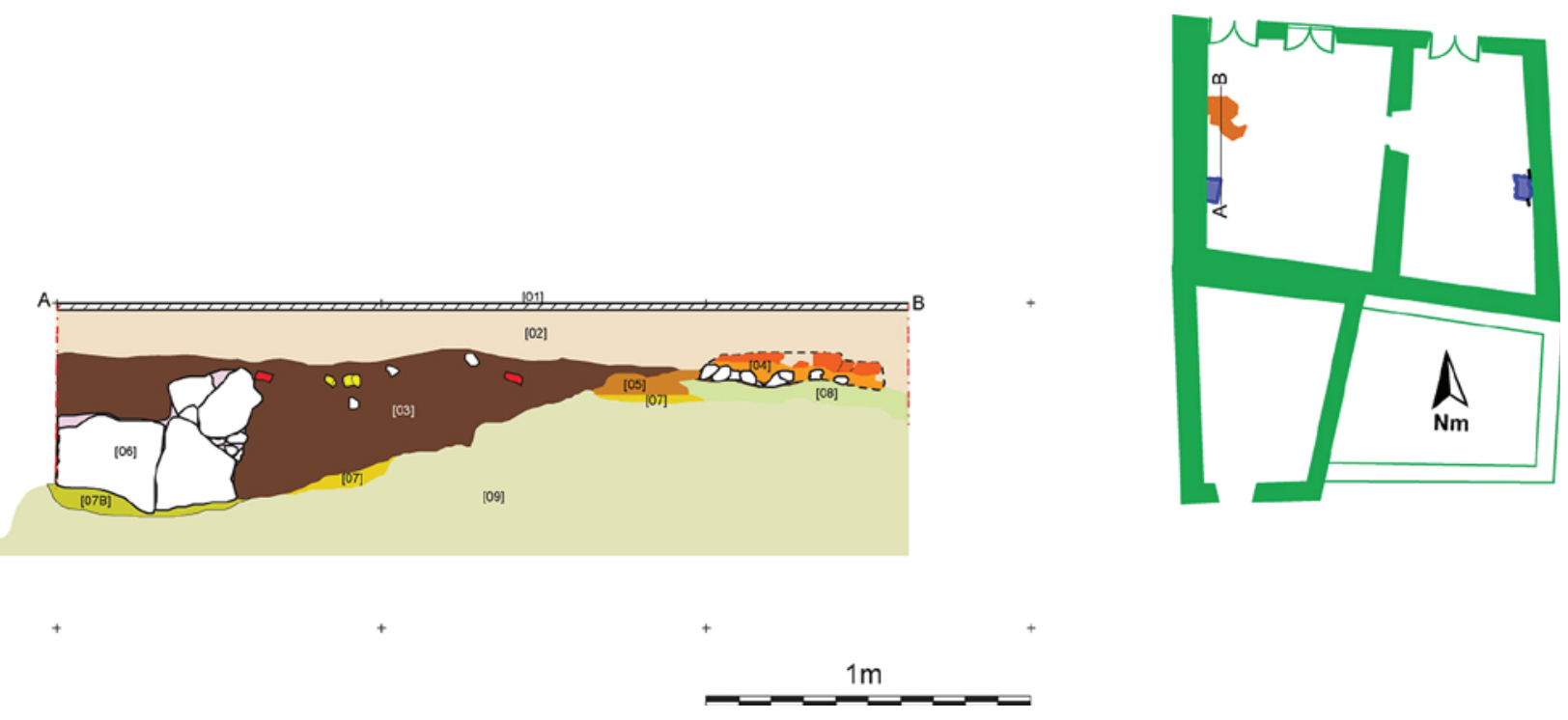

Figura 2-Sala 8, corte A-B do piso romano. 


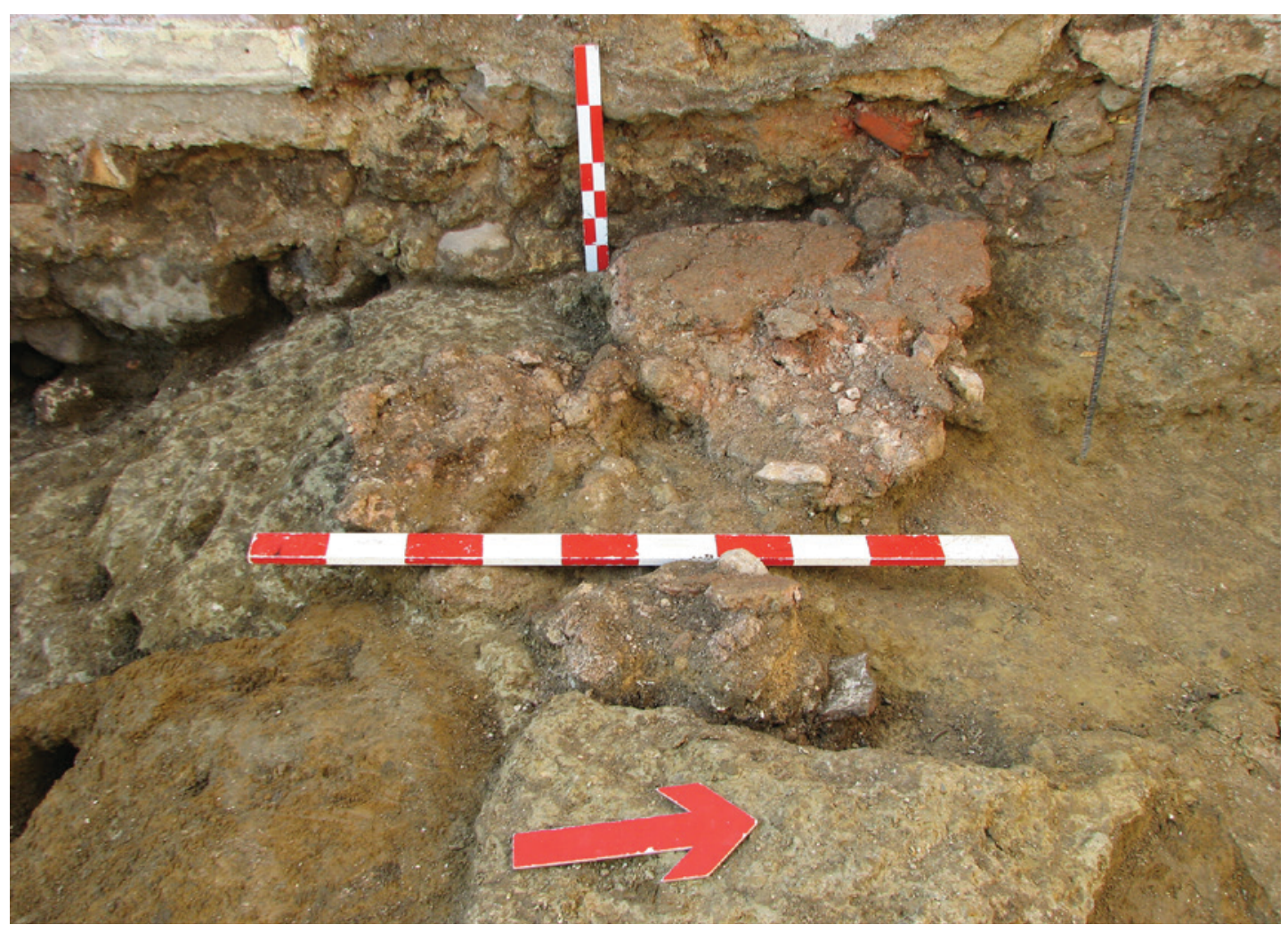

Figura 3 - Sala 8, vestígios de opus signinum.

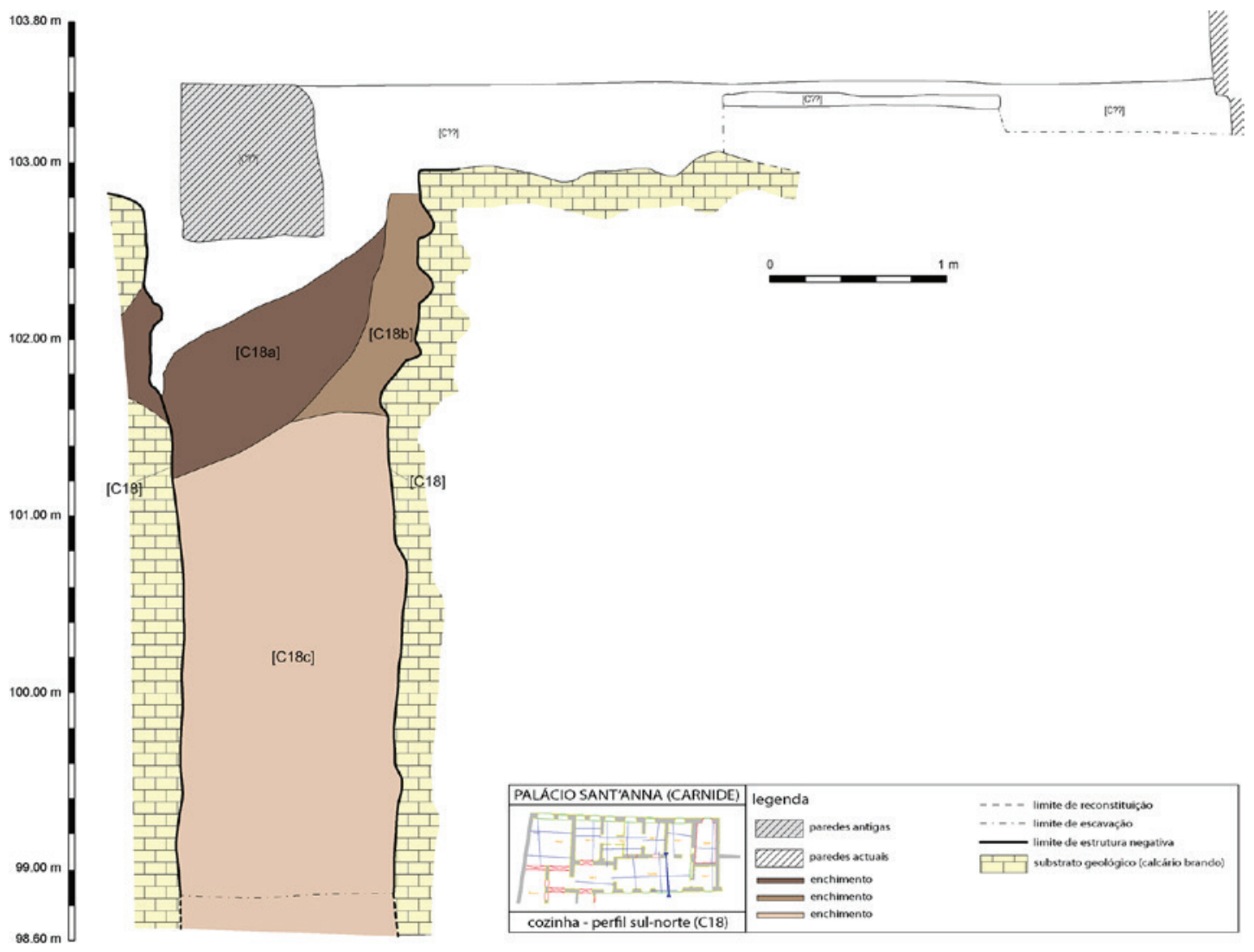

Figura 4-Corte do poço romano. 


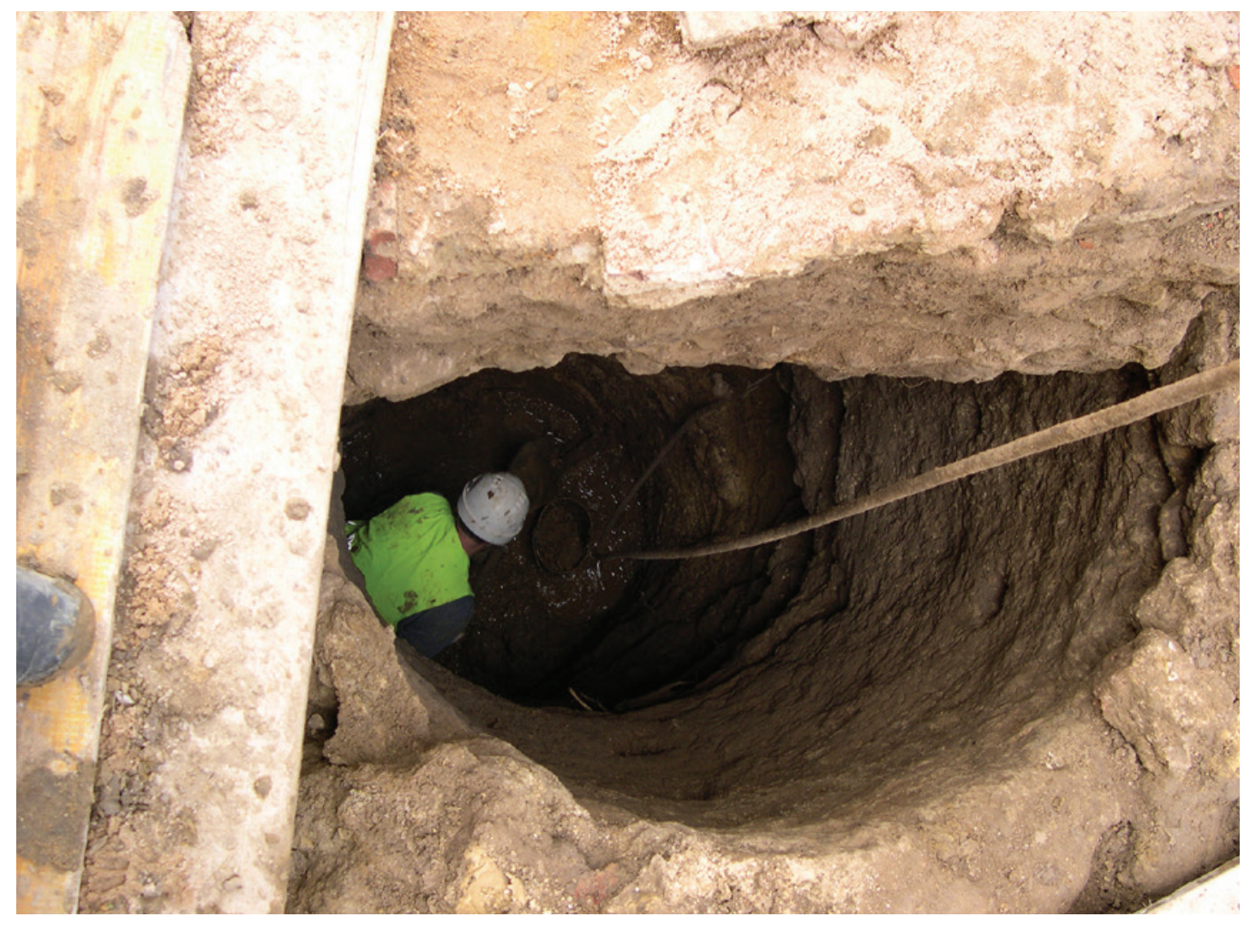

Figura 5- Poço romano.

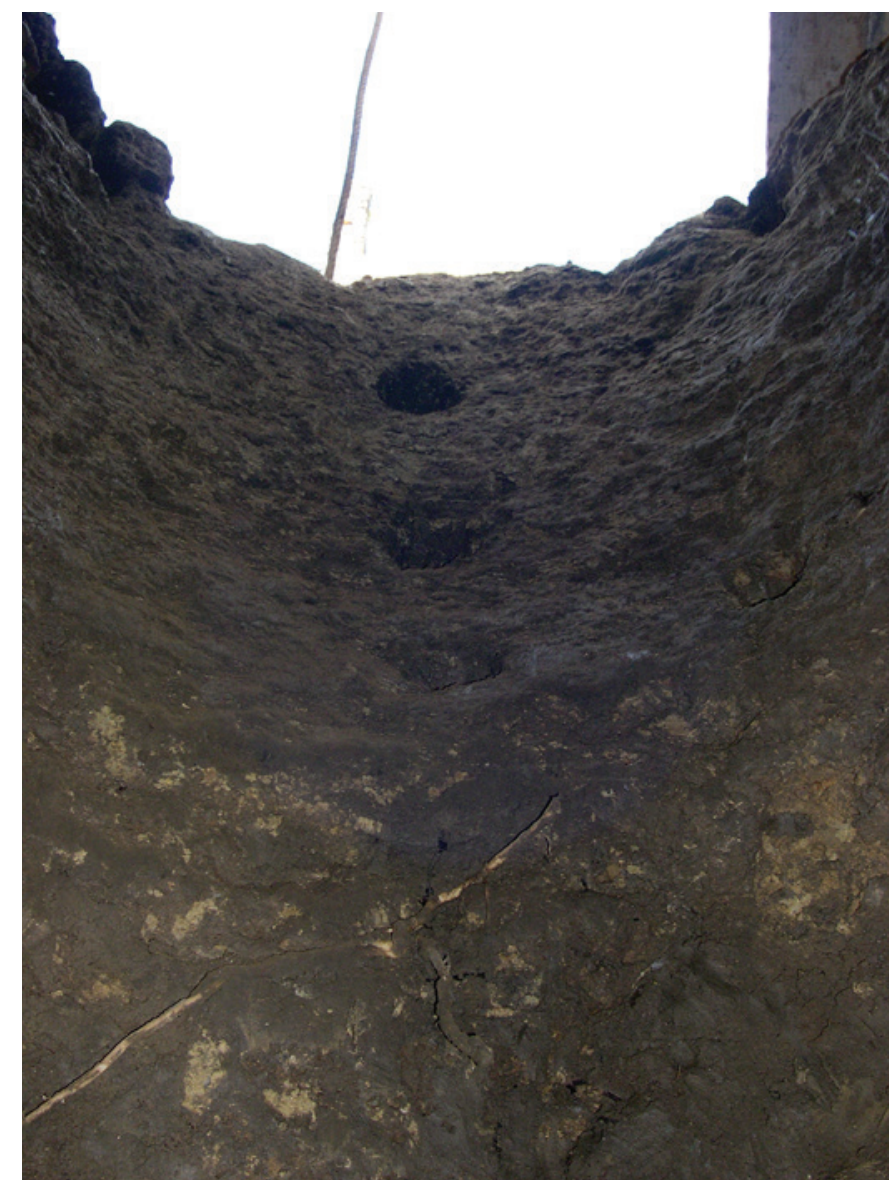

Figura 6 - Parede nascente do poço onde se vêm os buracos abertos na rocha. 


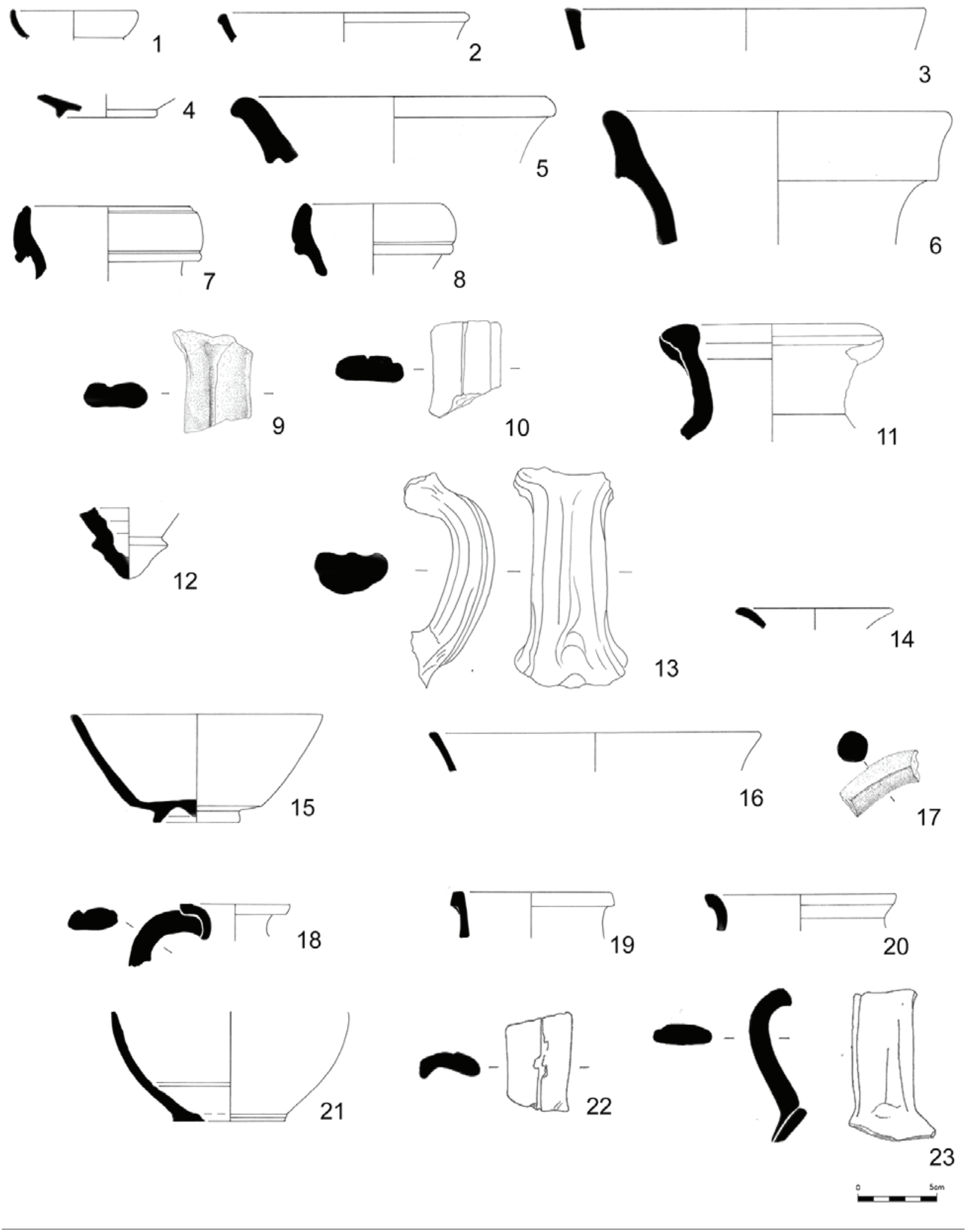

Figura 7-Desenhos de materiais 1 a 23. 

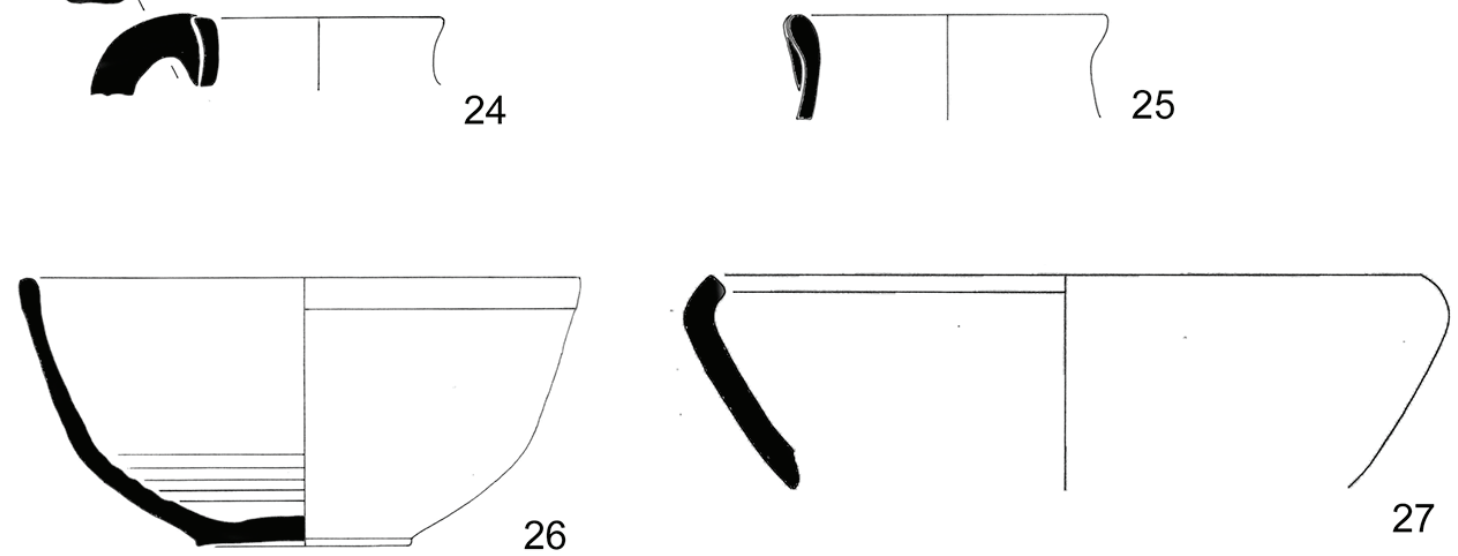

26
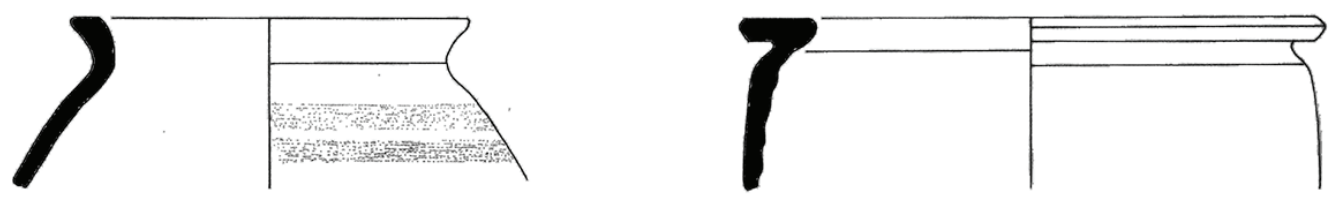

28
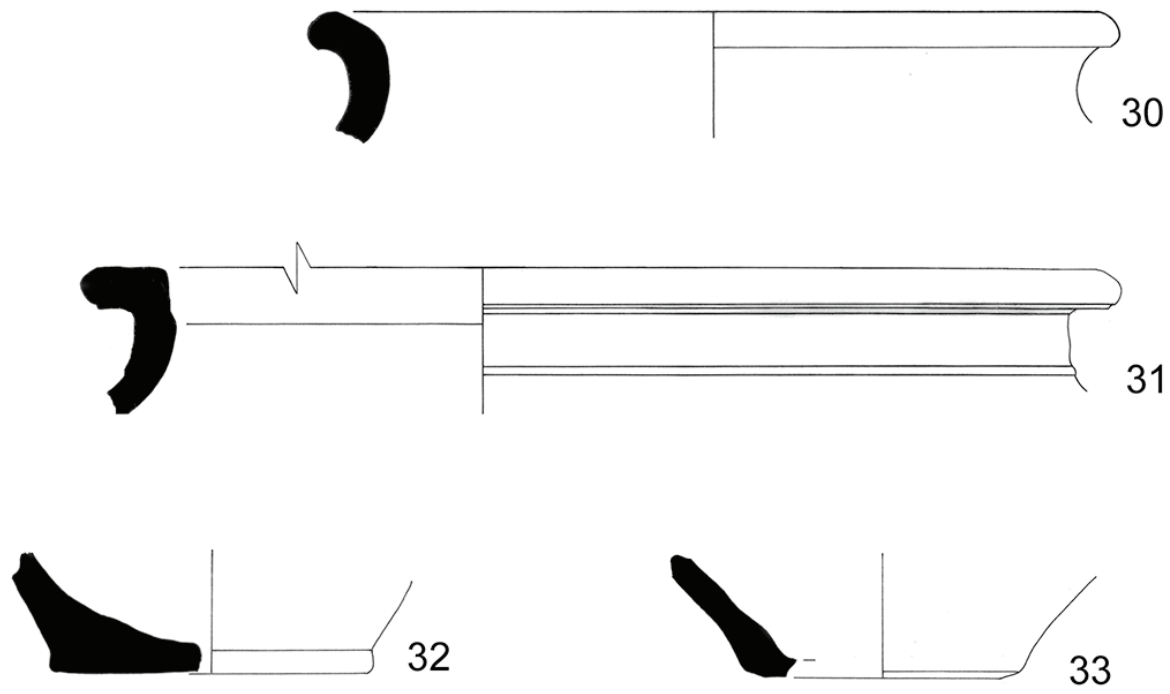

34
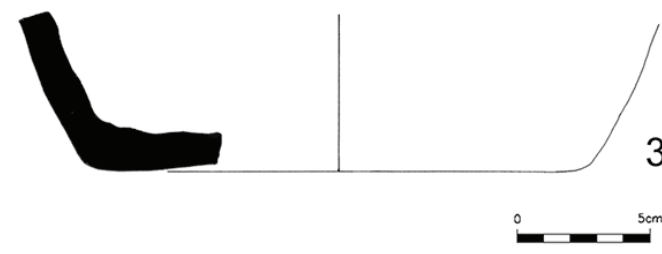

Figura 8-Desenhos de materiais 24 a 35 . 


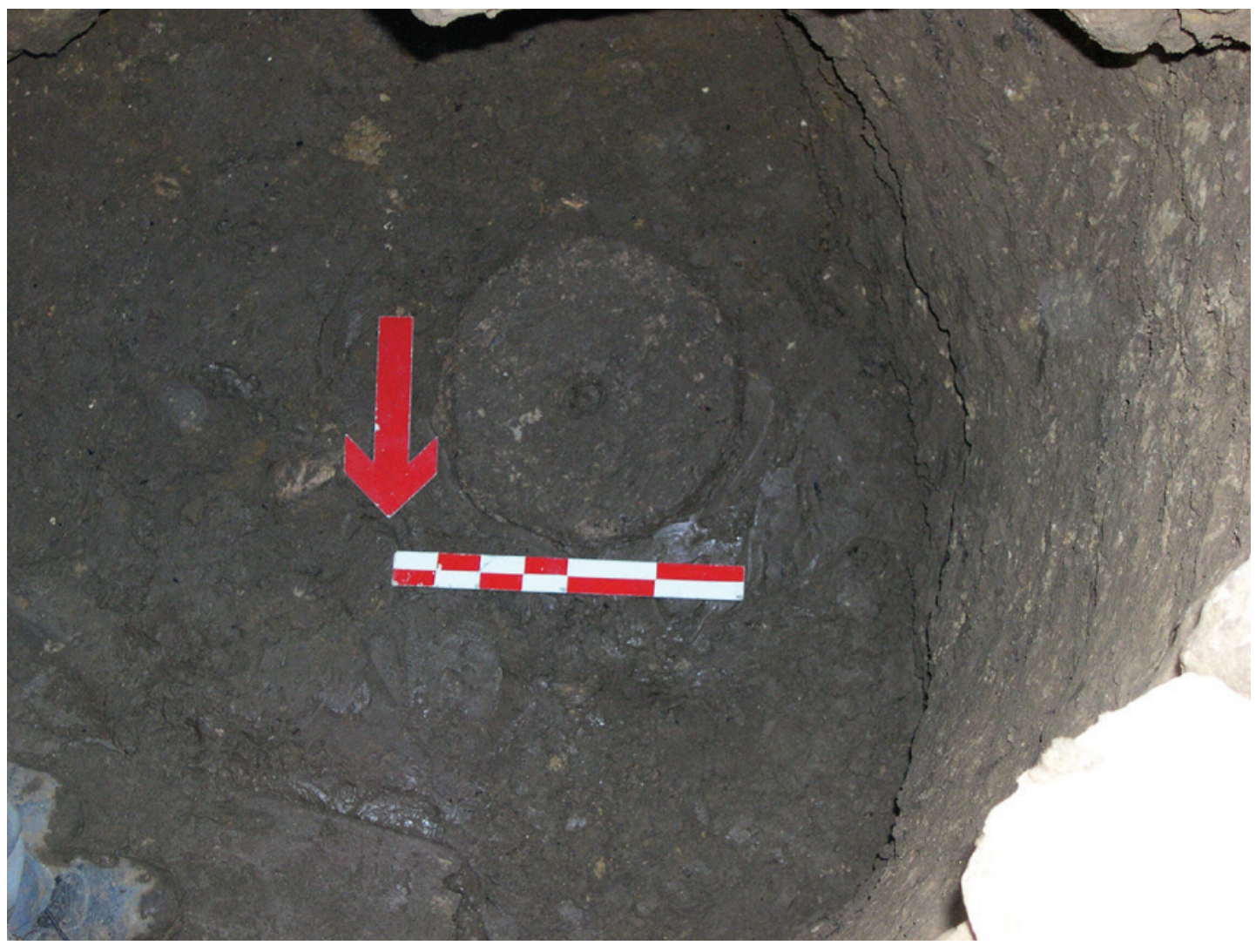

Figura 9- Fotografia do dormente de mó in situ no interior do poço.

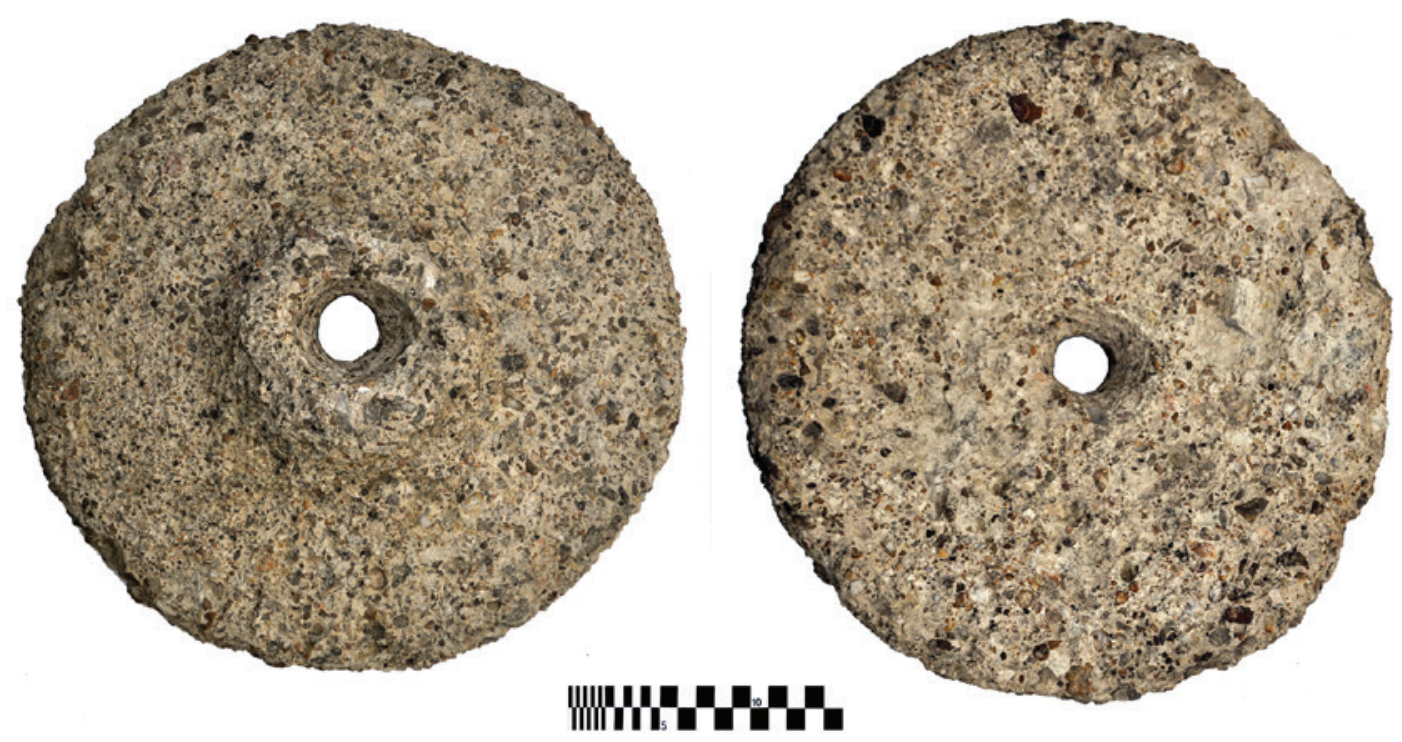

Figura 10 - Fotografia de dormente de mó recolhida no interior do poço. 


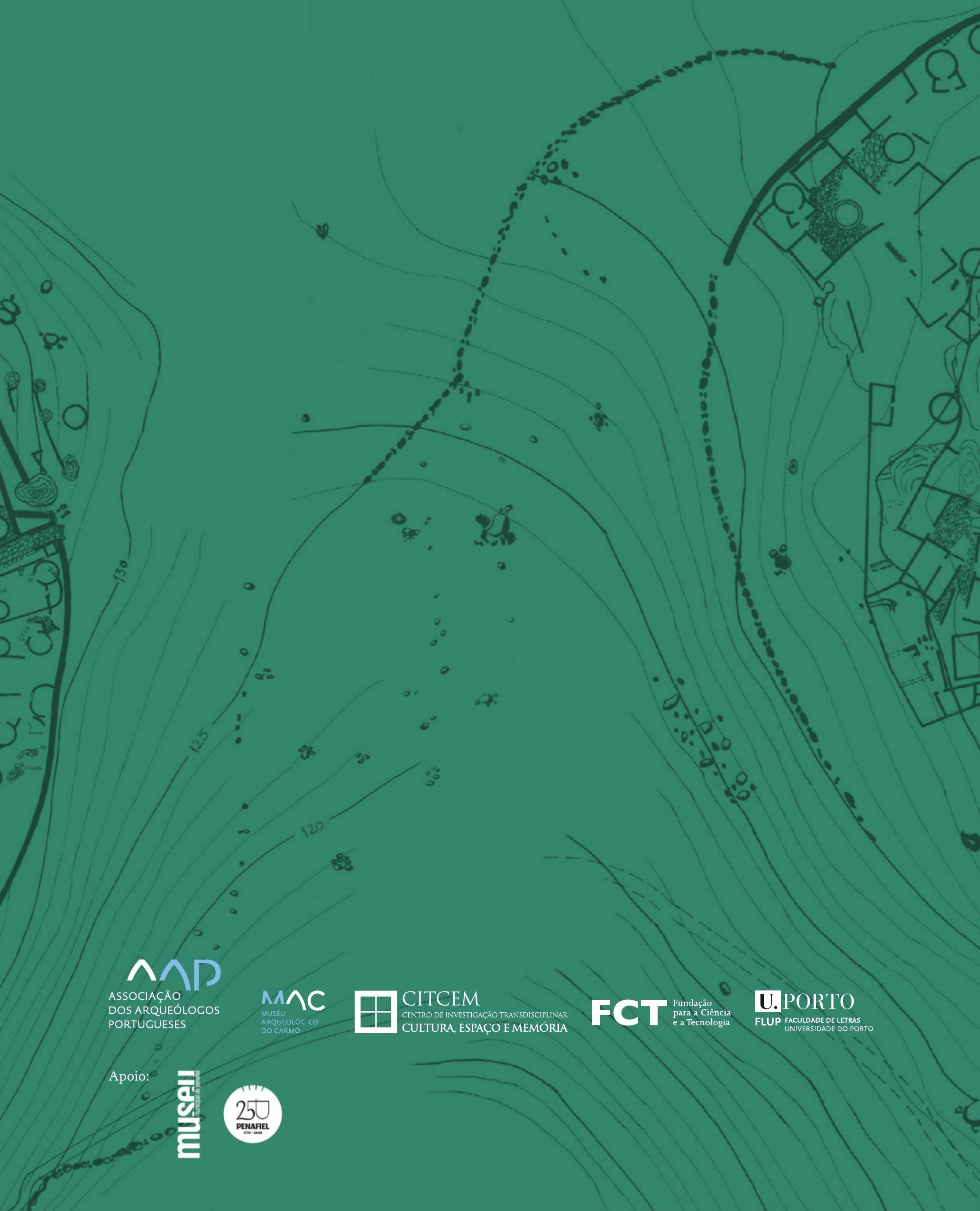

